\title{
Spatial approach of leprosy in the State of São Paulo, 2009-2012*
}

\author{
Flávia Regina Ferreira ${ }^{1}$, Luiz Fernando Costa Nascimento ${ }^{2}$
}

DOI: http:/ / dx.doi.org/10.1590/abd1806-4841.20197351

\begin{abstract}
BACKGROUND: Leprosy is a chronic, infectious disease that affects the skin and the peripheral nervous system and can lead to permanent disability and/or deformity.

Oвjectives: To identify the distribution and to quantify the spatial dependence of the detection rates of new cases of Hansen's disease in the State of São Paulo, correlating with socioeconomic variables.

METHODs: Ecological and exploratory study with data on the detection rates of new cases of Hansen's disease among residents of São Paulo State municipalities between 2009-2012. The average rate per 10,0000 inhabitants was estimated. Information on the proportion of the population with low-income and the values of the Gini index were obtained. Thematic maps were constructed with the average rates and with those obtained by the Bayesian estimator; Moran and Kernel maps were also constructed. Spatial analysis by TerraView program. An alpha of $5 \%$ was adopted.

RESULTS: In total, 7163 new cases of Hansen's disease were recorded throughout the state. The average rate per 10,000 inhabitants, was $0.71(\mathrm{SD}=1.06)$, ranging from zero to 12.87 , with higher rates in the west of the State, in the metropolitan area of the capital and the Paraiba Valley. Municipalities with high priority for intervention were located in the west and northwest of the State. There was no correlation between rates with Gini index and low income.

STUDY LIMITATIONS: Possible inconsistency of Hansen's disease notification database regarding information quantity, quality and processing.

Conclusions: This study identified the distribution and quantified the spatial dependence of the detection rates of new cases of Hansen's disease in the State of São Paulo, corroborating previous studies and serving as a subsidy to health managers. Keywords: Epidemiological monitoring; Geographic information systems; Leprosy; Socioeconomic factors; Spatial analysis
\end{abstract}

\section{INTRODUCTION}

Hansen's disease is a chronic, infectious and contagious disease that affects the skin and the peripheral nervous system and can lead to physical disability and/or permanent deformities. It is a stigmatizing disease for the patient, resulting in impairment and even segregation from their social relationships and professional

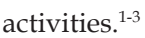

The World Health Organization (WHO) defined the reduction of the coefficient of prevalence to less than one case per 10,000 inhabitants for the elimination of Hansen's disease as a public health problem. ${ }^{2,4-6}$ However, according to Opromolla et al, the coefficient of prevalence is highly influenced by operational aspects of Hansen's disease programs and in order to monitor the endemic,

\footnotetext{
Received 15 June 2017.

Accepted 06 February 2018.

* Work conducted at Universidade de Taubaté, Taubaté (SP), Brazil.

Financial support: None.

Conflict of interest: None.

Discipline of Dermatology, Department of Medicine, Universidade de Taubaté, Taubaté (SP), Brazil.

Envirommental Science Post-Graduation Program, Universidade de Taubaté, Taubaté (SP), Brazil.
}

MAILING AdDRESS:

Flávia Regina Ferreira

E-mail: dermagica@uol.com.br 
an alternative and better indicator would be the rate of the detection of new cases. ${ }^{4}$

Among the 11 countries considered by the WHO as most endemic for Hansen's disease, India occupies the $1^{\text {st }}$ place and Brazil the $2^{\text {nd }}$ in number of detected cases. ${ }^{5}$

In 2014, Brazil's prevalence and detection coefficients of 1.27 were 1.53 cases per 10,000 inhabitants, respectively. In that same year, the State of São Paulo had a total of 1464 new cases, denoting a coefficient of detection of 0.33 case per 10,000 inhabitants. ${ }^{7}$ The study of the spatial behavior of this indicator (coefficient of detection) and the evaluation of its spatial dependency can be valuable tools.

A growing interest for the exploration of techniques of spatial representation of data in healthcare, that enable the identification of clusters with higher occurrence of a particular outcome and the visualization of the distribution of these events by the managers, guiding decision-making, is seen in Brazil..$^{1-5,8-12}$

Thus, the objectives of this study were: to identify the distribution and quantify the spatial dependency of the mean rates of detection of Hansen's disease in the State of São Paulo during the period between 2009 and 2012 according to some socioeconomic variables, using techniques of geostatistics.

\section{METHODS}

It is an ecological study because it is based on population data, and also exploratory, carried out with information about rates of detection of new cases of Hansen's disease in residents of the municipalities of the State of São Paulo from 2009 to 2012. This four-year period was chosen to smoothen possible data fluctuation. The data were obtained from the Centro de Vigilância Epidemiológica "Prof. Alexandre Vranjac" - CVE/SES-SP. ${ }^{13}$

Data from the population in these municipalities were collected and the detection rates of new cases of Hansen's disease per 10,000 inhabitants were calculated. The digital base of the municipalities was obtained from the Instituto Brasileiro de Geografia e Estatística - IBGE. ${ }^{14}$ Information on the ratio of the low-income population according to the municipalities and the values of the Gini index, which evaluates social inequality, ranging from 0 to 1 (the closer to 1 , the higher the inequality) were obtained. ${ }^{15}$

A thematic map was constructed using tools of spatial analysis and the Moran's Index $\left(\mathrm{I}_{\mathrm{m}}\right)$ was calculated, with its respective p-value, which estimates the spatial autocorrelation of the rates found; this index ranges from -1 to +1 . Values close to zero indicate the nonexistence of a spatial autocorrelation, i.e. events are random, and values close to one indicate the higher similarity among neighbors. Negative values mean they are dissimilar. ${ }^{16}$

Moran, Kernel and global empiric Bayesian maps were also constructed.

The aim of Moran's map is to demonstrate which municipalities have low or high priority of intervention for the reduction of the event being studied (new cases of Hansen's disease) and deserve more attention from the managers.

Kernel's map is a statistical method that enables to estimate the density of cases with smoothing of the rates to identify hotspots (hot areas with high density of cases). The method is based in the calculation of the density of cases (number of cases per area), gen- erating a surface of probabilities where areas with closer cases have a higher risk, and the denominator used for the rate is, in another layer, the density of people (inhabitants per area or demographic density), also as continuous surface. In this study, the estimator of Kernel comprised 150 rows, quartic function and adaptive radius; the accuracy and the number of slices used were 10 .

The empiric Bayesian estimator is a method that allows smoothing the fluctuation associated to small areas. In the global Bayesian analysis, the mean used in the evaluation is a mean rate of the whole region of study (all municipalities). Therefore, considering that the municipalities have a determined median incidence rate of an event, it enables to estimate which should be the real rates for these municipalities, better reflecting the real risk of detection of cases for the event and not the presence of random fluctuation. ${ }^{16}$

Because it is an ecological study where the subject is not identified, submission to the committee of ethics and research was not necessary.

The spatial analysis was performed using the program TerraView 4.2.2, provided by the Instituto Nacional de Pesquisas Espaciais - INPE.

The level of significance adopted was of alpha $=5 \%$.

\section{RESULTS}

In the whole of the State of São Paulo, 7163 new cases of Hansen's disease were identified between 2009 and 2012, ranging from zero to 983 .

The mean rate of cases was $0.71(\mathrm{SD}=1.06)$, ranging from 0 to 12.87 .

Moran's index was $I_{m}=0.03$ and $p$-value $=0.09$, showing the lack of significant spatial autocorrelation. Even without significant spatial autocorrelation, it is possible to identify municipalities with high rates of detection of new cases in the thematic map (8.65 per hundred thousand inhabitants and more), located on the western region of the State, in the metropolitan region of the capital and in some municipalities of the Paraíba Valley (Figure 1A).

The global Bayesian approach showed $\mathrm{I}_{\mathrm{m}}=0.04$ and $\mathrm{p}$-value $=0.05$. In this map, we can observe that many municipalities had rates of detection of new cases sometimes higher, sometimes lower than those shown by the thematic map (Figures 1A and 1B). This type of analysis was significant for spatial correlation ( $p$-value $=0.05$ ).

Moran's map, identifying municipalities with high and low priority of intervention can be seen in figure 2. In quadrant A-A (high priority of intervention), 18 municipalities of the State are found.

Kernel's map shows a higher density of cases (hotspots) in the northeast and west of the State, as well as in the metropolitan region of the capital and towards the central and coastal regions (Figure 3).

Figure 4 contains the values of Gini's index and shows strong spatial correlation, with Moran's index of $\mathrm{I}_{\mathrm{m}}=0.22(\mathrm{p}=0.01)$. The greatest social inequalities can be seen in the metropolitan region of the capital, in the south of the State, along the coast and in the Paraíba Valley.

Figure 5 on the proportion of municipalities with low income also shows a strong spatial correlation $\left(\mathrm{I}_{\mathrm{m}}=0.56\right.$ and $\mathrm{p}$-value $<0.01$ ). The municipalities with higher ratios of low income are concentrated in the far west, in the southern region of the State and in the Paraíba Valley, similar to the distribution of Gini's index. 


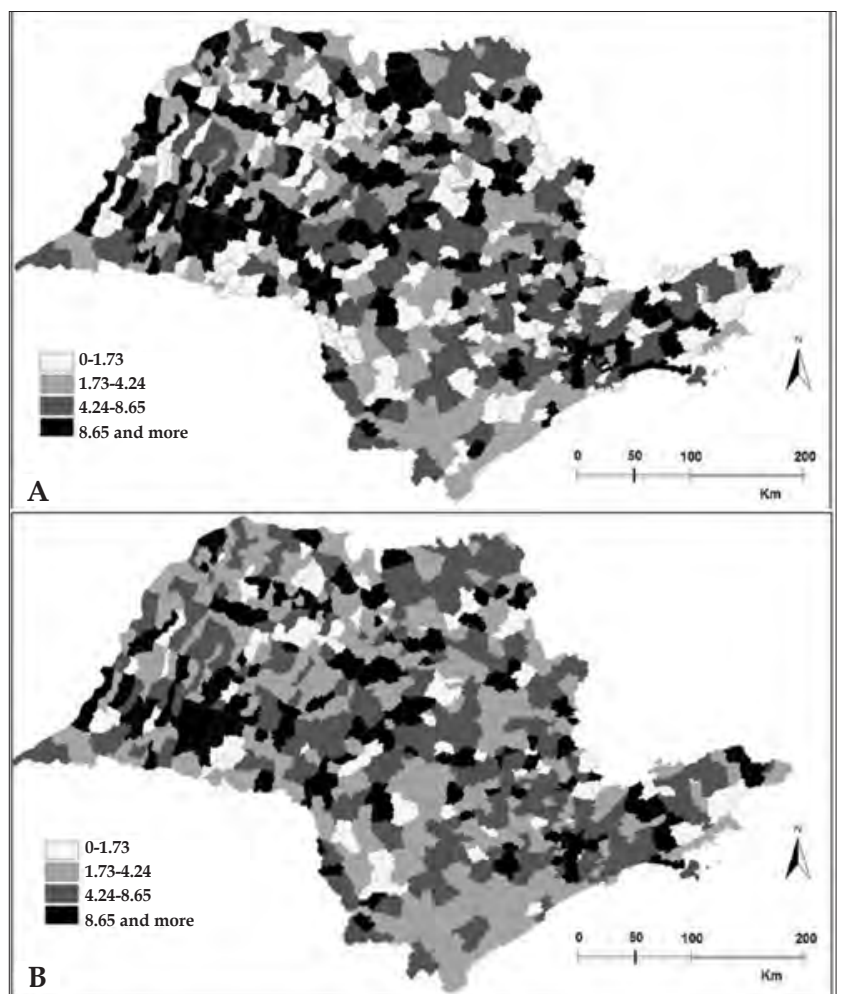

Figure 1: Detection rates of new cases of Hansen's disease per 100,000 inhabitants. A - Thematic map. B - Bayesian approach. State of São Paulo, Brazil, 2009-2012

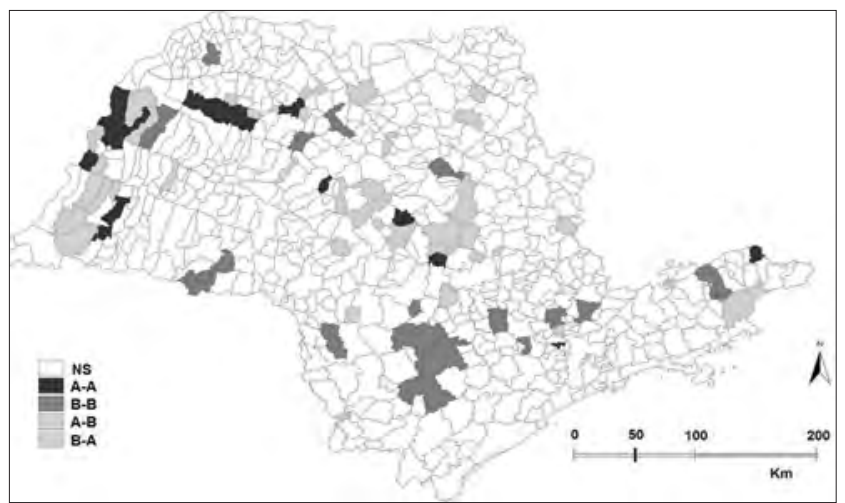

Figure 2: Moran's map. State of São Paulo, Brazil, 2009-2012. High-High is High - High; Low-Low is Low-Low; A-B is High-Low and Low-High is Low-High

\section{DISCUSSION}

Physical disabilities and deformities are the main issues of Hansen's disease, affecting individuals of working age, interfering in work activities and resulting in not only economic but also social/psychological losses, impacting the quality of life. ${ }^{1-3}$

It is important to understand the epidemiology of Hansen's

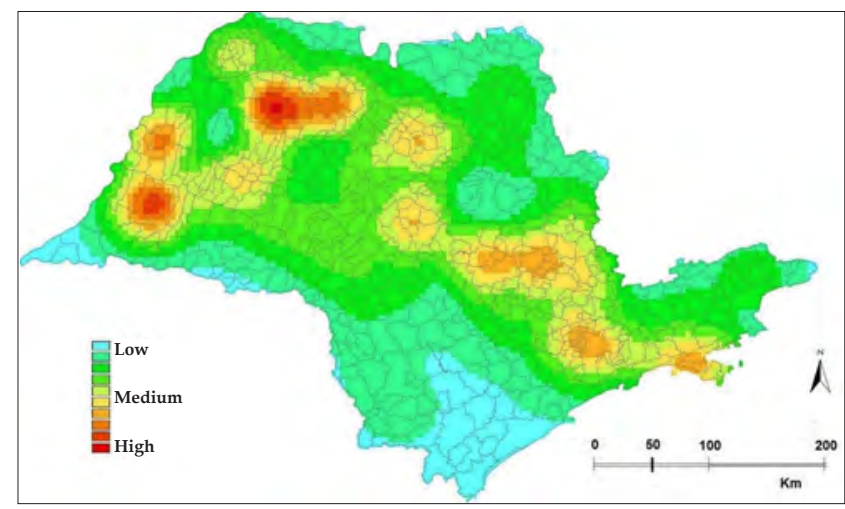

Figure 3: Kernel map. State of São Paulo, Brazil, 2009-2012

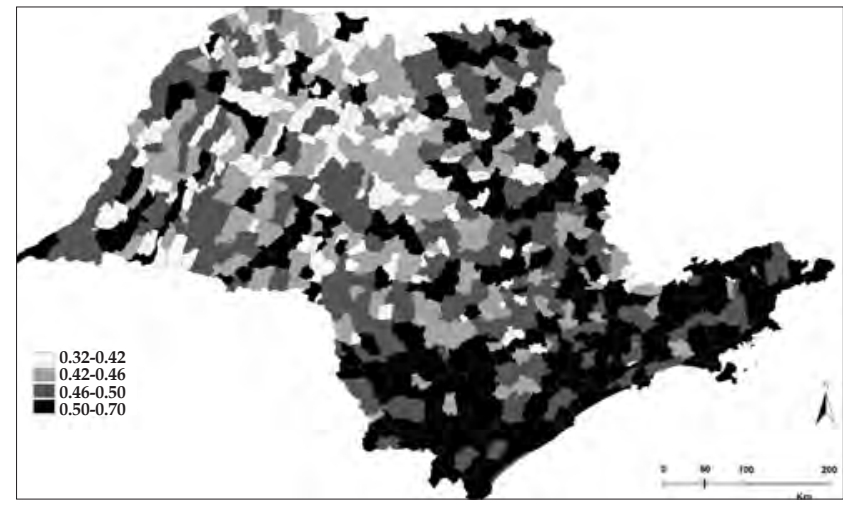

Figure 4: Thematic map with the values of Gini's index. State of São Paulo, Brazil, 2009-2012

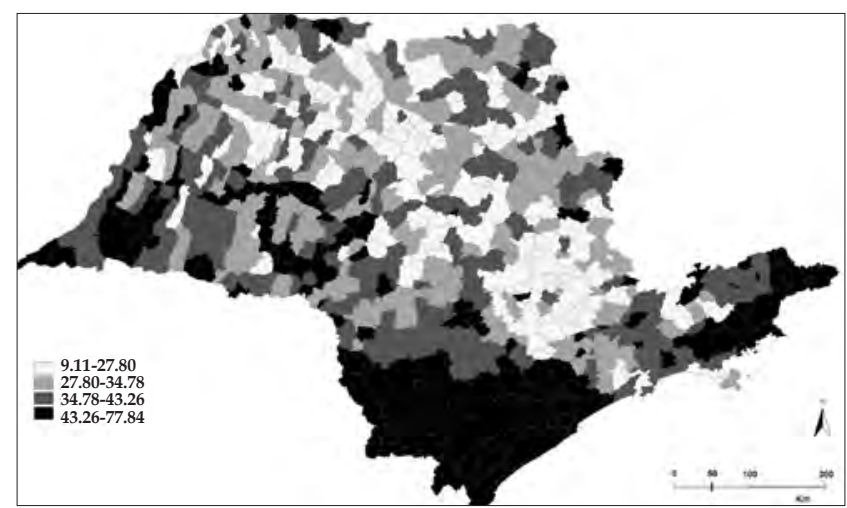

Figure 5: Thematic map of the proportion of municipalities with low income, in percentages. State of São Paulo, Brazil, 2009-2012

disease in the countries that were able to eliminate it and precisely locate critical areas that deserve special attention to eliminate Hansen's disease from areas still considered endemic such as Brazil. ${ }^{2}$

The distribution of Hansen's disease in the State of São Paulo, as all over Brazil, is uneven. ${ }^{2,4}$ It is necessary that managers understand the local epidemiological situation to define priority actions. The spatial analysis using techniques of geostatistics makes 
it possible to recognize risk areas. However, this instrument needs accurate information. A possible limitation of this study is the inconsistency of the database of Hansen's disease notification regarding the quantity, quality and processing of information. However, the analysis of four grouped years enabled the identification of spatial clusters with higher detection rates of new cases of Hansen's disease, minimizing possible data fluctuation.

The mean rate of cases detected in this study for the State of São Paulo proved to be more than double of that announced by the Ministry of Health for this State in $2014 .^{7}$ Is it a new epidemiological reality or the absence of actions in search of new cases?

The higher detection rates of new cases identified in the western and northeastern regions of the State were in accordance to Opromolla et al's findings (possible relationship with the migratory behavior of these regions) and could be contributing to the appearance of new cases in the Midwest of the country as reported by Ignotti et al. ${ }^{4,17}$

In the metropolitan region of the capital, the uncontrolled growth of the population associated to population movements (coming from the countryside of the State - rural areas - and/or other regions of the country, North-Northeast in particular), with no improvements in urban structure and subsequent impairment in the living conditions of these populations (formation of slums) can possibly justify the high detection rates found. ${ }^{18,19}$

Studies show the strong relationship between Hansen's disease and socioeconomic conditions in Brazil and in the world. ${ }^{20,21}$
Contrary to the previous statement and to the findings by Lapa $e t l^{22}$ in Olinda, who identified a heterogeneous spatial distribution of Hansen's disease in this municipality followed by a pattern of spatial clustering associated to the living conditions of the population expressed as an indicator of social deprivation, in this study, the spatial distribution (clusters with higher rates of detection of new cases) of Hansen's disease in the State of São Paulo did not coincide with the spatial clusters associated to worse social inequa-lity (Gini's index) or too low income. This is possibly explained in the better organization of healthcare services and, consequently, in the more efficient detection of cases of Hansen's disease in more socioeconomically favored areas. However, it also possibly highlights flaws in healthcare services of less favored regions, resulting in under notification and/or late diagnosis, consequently enabling higher occurrence of disabilities and/or deformities.

\section{CONCLUSIONS}

This study made it possible to identify the distribution and quantify the spatial dependency of the mean rates of detection of Hansen's disease in the State of São Paulo, with a predominance in the northern and northeastern regions of the State in accordance with the literature and acting as subsidy to managers for the planning of interventions that allow to change this picture in future studies. The relationship Hansen's disease/low socioeconomic condition was not confirmed in this study.

\section{REFERENCES}

1. Amaral EP, Lana FCF. Análise espacial da Hanseníase na microrregião de Almenara, MG, Brasil. Rev Bras Enferm. 2008;61:701-7.

2. Gauy JS, Hino P, Santos CB. Distribuição espacial dos casos de hanseníase no município de Ribeirão Preto no ano de 2004. Rev Latino-Am Enfermagem. 2007;15:460-65.

3. Cury MR, Paschoal VD, Nardi SM, Chierotti AP, Rodrigues Júnior AL, ChiaravallotiNeto F. Spatial analysis of leprosy incidence and associated socioeconomic factors. Rev Saude Publica. 2012;46:110-8

4. Opromolla PA, Dalben I, Cardim M. Análise da distribuição espacial da hanseníase no Estado de São Paulo, 1991-2002. Rev Bras Epidemiol. 2005;8:356-64.

5. Duarte- Cunha M, Souza-Santos R, Matos HJ, Oliveira MLW. Aspectos epidemiológicos da hanseníase: uma abordagem espacial. Cad. Saúde Pública. 2012;28:1143-55.

6. Magalhães MCC, Rojas LI. Evolución de la endemia de la lepra en Brasil. Rev Bras Epidemiol. 2005;8:342-55.
7. Portalsaude.saude.gov.br [Internet]. Brasil. Ministério da Saúde. Registro ativo: número e percentual, Casos novos de hanseníase: número, coeficiente e percentual, faixa etária, classificação operacional, sexo, grau de incapacidade, contatos examinados, por estados e regiões, Brasil, 2014 [cited 2016 Sep 11]. Available from: http://portalsaude.saude.gov.br/images/pdf/2015/julho/27/ Dados-2014---final.pdf

8. Almeida MC, Gomes CM, Nascimento LF. Spatial analysis of neonatal mortality in the state of São Paulo, 2006-2010. Rev Paul Pediatr. 2014;32:374-80.

9. Venâncio TS, Tuan TS, Nascimento LF. Incidence of tuberculosis in children in the state of São Paulo, Brazil, under spatial approach. Cien Saude Colet. 2015;20:1541-7

10. Mukai A0, Nascimento LFC, Alves KSC Análise espacial das internações por pneumonia na região do Vale do Paraíba (SP). J Bras Pneumol. 2009; 35:753-8.

11. Amancio CT, Nascimento LF. Cutaneous melanoma in the State of São Paulo: a spatial approach. An Bras Dermatol. 2014;89:442-6. 
12. Ferreira FR, Nascimento LF. Mortality due to cutaneous melanoma in south region of Brazil: a spatial approach. An Bras Dermatol. 2016;91:437-41.

13. Saude.sp.gov.br [Internet]. Governo do Estado de São Paulo. Secretaria de Estado da Saude. Centro de Vigilância Epidemiológica Prof. Alexandre Vranjac. Hanseníase. Dados estatísticos [cited 2019 Apr 25]. Available from: http:// www.saude.sp.gov.br/cve-centro-de-vigilancia-epidemiologica-prof.-alexandrevranjac/areas-de-vigilancia/hanseniase/dados-estatisticos.

14. Ibge.gov.br [Internet]. Brasil. Instituto Brasileiro de Geografia e Estatística. Geociências [cited 2014 Mar 3]. Available from: http://downloads.ibge.gov.br/ downloads_geociencias.htm.

15. Datasus.gov.br [Internet]. Brasil. Ministério da Saúde. Departamento de Informática do Sistema Único de Saúde do Brasil. Demográficas e socioeconômicas [cited 25 Apr 2016]. Available from: http://www2.datasus.gov.br/DATASUS/index. php?area $=0206$.

16. Escoladesaude.pr.gov.br [Internet]. Ministério da Saúde, Fundação Oswaldo Cruz; Santos SM, Souza WS, orgs. Introdução à estatística espacial para saúde pública. Brasília: Ministério da Saúde; 2007. (Série: Capacitação e Atualização em Geoprocessamento em Saúde) [cited 25 Apr 2016]. Available from: http:// www.escoladesaude.pr.gov.br/arquivos/File/TEXTOS_CURSO_VIGILANCIA/ capacitacao_e_atualizacao_em_geoprocessamento_em_saude_3.pdf.
17. Ignotti E, Rodrigues AM, Andrade VL, Valente JG. Aplicação de métodos de estimativas de hanseníase no Estado de Mato Grosso. Rev Bras Epidemiol. 2004;7:155-66.

18. Pasternak S, Bogus LMM. Migração na metrópole. São Paulo Perspec 2005;19:21-47.

19. Pasternak S, D' Ottaviano C. Favelas no Brasil e em São Paulo: avanços nas análises a partir da Leitura Territorial do Censo de 2010. Cad Metrop. 2016:18:75-99.

20. Cunha SS, Rodrigues LC, Duppre NC. Current strategy for leprosy control in Brazil: time to pursue alternative preventive strategies? Rev Panam Salud Publica. 2004;16:362-5

21. Kerr-Pontes LR, Montenegro AC, Barreto ML, Werneck GL, Feldmeier H. Inequality and leprosy in Northeast Brazil: an ecological study. Int J Epidemiol. 2004;33:262-9.

22. Lapa T, Ximenes RAA, Silva NN, Souza WV, Albuquerque MFM, Campozana G. Vigilância da hanseníase em Olinda, Brasil, utilizando técnicas de análise espacial. Cad Saúde Pública. 2001:17:1158-62.

\section{AUTHORS'CONTRIBUTIONS}

$\begin{array}{lll}\text { Flávia Regina Ferreira } & \text { (iD) ORCID 0000-0001-5679-4282 }\end{array}$

Approval of the final version of the manuscript; Conception and planning of the study; Elaboration and writing of the manuscript; Obtaining, analyzing and interpreting the data; Critical review of the literature; Critical review of the manuscript

Luiz Fernando Costa Nascimento $\quad$ (ID) ORCID 0000-0001-9793-750X

Statistical analysis; Approval of the final version of the manuscript; Conception and planning of the study; Elaboration and writing of the manuscript; Obtaining, analyzing and interpreting the data; Effective participation in research orientation; Critical review of the literature; Critical review of the manuscript

How to cite this article: Ferreira FR, Nascimento LFC. Spatial approach of leprosy in the State of São Paulo, 2009-2012. An Bras Dermatol. 2019;94(1):37-41. 